\title{
COMPRESSIVE STRENGTH AND DURABILITY OF CEMENT CONCRETE CONTAINING ALKALI WASTES OF OIL AND CELLULOSE PAPER INDUSTRIES AND EXPOSED TO AGGRESSIVE ENVIRONMENTAL CONDITIONS
}

\author{
Rashwan M. M, Mahmoud H. A, Aly G. A. and Abo-Elfadel, M. \\ Civil Engineering Department, Faculty of Engineering, Assiut University, Assiut, \\ Egypt
}

(Received April 26, 2006 Accepted May 24, 2006)

Most of R.C. constructions, especially underground, are always subjected to aggressive environmental conditions during their exploatation. These conditions are represented by the aggressive sodium and magnesium sulfate attack from surrounding soil or underground water. When cement-based materials are exposed to sodium sulfate attack, gypsum and ettringite are produced by chemical reactions of sulfate and $\mathrm{Ca}(\mathrm{OH})_{2}$, and $\mathrm{C}_{3} \mathrm{~A}$. Formation of gypsum plays an important role in the damage of materials. According to that, the actual compressive strength of R.C. elements decreases accompanied with large deformations of concrete. Consequently, a higher reduction of the construction durability occurs. So, the need for using an effective and economic admixtures for the protection of concrete elements against sulfate attack or any other environmental conditions is required.

Therefore, the main purpose of this research is to study experimentally the possibility of producing effective and economic admixtures from alkali wastes of oil and cellulose paper industries. Then study their mechanism effect on the compressive strength and durabiliyt of cement concrete specimens, subjected to external sulfate attack and different cycles of durability test. The main variables studied in this research on concrete mixes and hardened specimens were: -three different types of plasticizing organic admixtures(SM-S, CM-B \&SM-O), which contain in their compositions an amount of alkali wastes from secondary products of oil and cellulose paper industries, plus a known plasticizing admixture in the Egyptian markets (Addicrete DM2),- three different concentrations of external surrounded sodium and magnesium sulfate solutions and four different numbers of cycles of durability test.

The experimental results showed that, The optimum composition of all components of the suggested admixtures (SM-S, CM-B \& SM-O) containing alkali wastes from oil and cellulose paper industries and production of them in a liquidity solution was successfully and experimentally achieved. Concrete specimens modified with these admixtures and hardened in $6 \% \mathrm{Na}_{2} \mathrm{SO}_{4}+3 \% \mathrm{MgSO}_{4}$ until 7 months showed a large increase in their compressive strength by about 46, 37, \& $38 \%$ and a large increase of their durability index, after 50 cycles, by about $86,84 \& 76 \%$. respectively compared to the control tested specimens without admixtures. Microscopic analysis showed that specimens modified with the suggested organic admixtures have denser and homogeneous structure, their large pores decreased and micro pores increased 
compared to the control specimens. The vacuums of specimens containing these admixtures after 50 cycles of durability test were filled with prismatic new formations and showed a very small shrinkage cracks between cement paste and filling materials.

KEYWORDS: organic admixture, alkali wastes, compressive strength, concrete, sulfate attack, mechanism effect, aggressive, durability, microstructure.

\section{1- INTRODUCTION}

Sulfate attack on cement mortars or concrete leads to the conversion of hydrated products of cement to ettringite, gypsum and other phases, and also to the destabilization of the primary strength provided calcium silicate hydrate (C-S-H) gel. The formation of ettringite and gypsum is common in cementitious materials exposed to most types of sulfate solutions. The expansion resulting from sulfate attack is generally attributed to the formation of these two compounds, although there is some controversy surrounding the exact mechanisms causing expansion [1]. When attacking solution contains magnesium ions, such as magnesium sulfate $\left(\mathrm{MgSO}_{4}\right)$, the formation of magnesium hydroxide (brucite) and conversion of $\mathrm{C}-\mathrm{S}-\mathrm{H}$ into magnesium silicate hydrate M-S-H were observed [2,3]. In general, concrete has a low resistance to chemical attack. There are several chemical agents which react with concrete, but two forms of attack is most common, namely, leaching and sulfate attack. Chemical agents essentially react with certain compounds of the hardened cement paste and the resistance of concrete to chemical attack therefore depends largely on the type of cement used. The resistance of concrete to chemical attack has improved with increase of its impermeability [4]. The general reactions involved in external sulfate attack have been described previously by Cohen and Bentur [5].

When cement-based materials are exposed to sodium sulfate attack, gypsum and ettringite are produced by chemical reactions of sulfate and $\mathrm{Ca}(\mathrm{OH})_{2}, \mathrm{C}_{3} \mathrm{~A}$. Formation of gypsum plays an important role in the damage of materials $[5,6,7]$. There is a close relationship between $\mathrm{Ca}(\mathrm{OH})_{2}$ content and gypsum formation. Ettringite formation results in cracking and expansion of the material. Expansion is related to the water absorption of crystalline ettringite. So, it is necessary to increase the resistance of concrete against sulfate attack. Some researchers used pozzolanic, dolomite, fly ash, and silica fume materials in the technology of concrete for the increase its resistance to sodium sulfate attack. These materials react with $\mathrm{Ca}(\mathrm{OH})_{2}$ and the result is additional $\mathrm{CSH}$ gel. This transformation leads to the increase of cement materials resistance to sodium sulfate attack $[5,8,9$, and 10$]$.

Over the past several years, there has been a concerned research effort to explore the mechanism effect of chemical plasticizing admixtures on the mechanical properties of R.C. structures. Increasing the concrete alkali content from $0.6 \%$ to $1.25 \%$ of $\mathrm{Na}_{2} \mathrm{O}_{\mathrm{e}}$ of the cement mass by adding alkali addition to the mixture water has harmful effects on most mechanical properties (compressive, splitting, direct tensile, and flexure strengths) of concrete $[11,12]$. Admixtures, which contain in their compositions organic materials with limited doses, represent practical interest especially for our local country conditions. This practical interest attractive more 
investigators because of their availability and outstanding advantages such as: high compressive and tensile strength of concrete, durable concrete in aggressive environmental conditions, suitable resistance to corrosion, very low cost and not causing epidemic for organism of man $[13,14]$.

The organic materials can be obtained from the secondary products and alkali wastes of vegetable oil, chemical synthesis and cellulose paper industries. The solubility mechanism of organic elements with water and mechanism of water adsorption on an organic or inorganic surface of a material are shown in Figs. 1\& 2. Mechanism effect of organic elements on cement particles and on formation space of coagulate structure of cement material are shown in Figs. $3 \&$ 4. The action of organic elements on cement paste and concrete mixture is determined by the structure of their molecules and correlation between organic and non-organic particles of their molecules. It is known that, organic elements have the ability of adsorption on the surfaces of cement particles and solid phase. They also take part in formation space, coagulate structure and orientation molecules. The initial development of producing concrete with organic admixtures technique took place in the USSR laboratories for materials testing and research, which have highlighted the effect of organic materials on concrete properties since 1981. Many research works have been focused on the application of organic admixtures in the technology of concrete and reinforced concrete structures. Because of their positive influence on the physical and mechanical properties of R.C. elements not only on their early period of hardening, but also for the period of their exploitation in the building site [13-18].

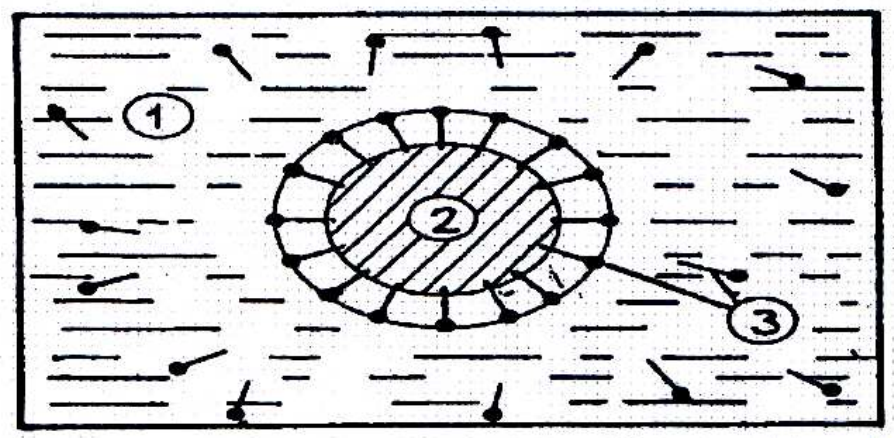

Fig. 1: Solubility mechanism of organic elements with water.

1- water solution of dissolving material, 2- organic element (alkali wastes) 3-elements of dissolving material such as $\mathrm{CaO}$ or superplasticizers



(a)



(b)

Fig. 2:Mechanism of water adsorption on an organic or inorganic surface of a material a) Inorganic surface of a material, b) Organic surface of a material 


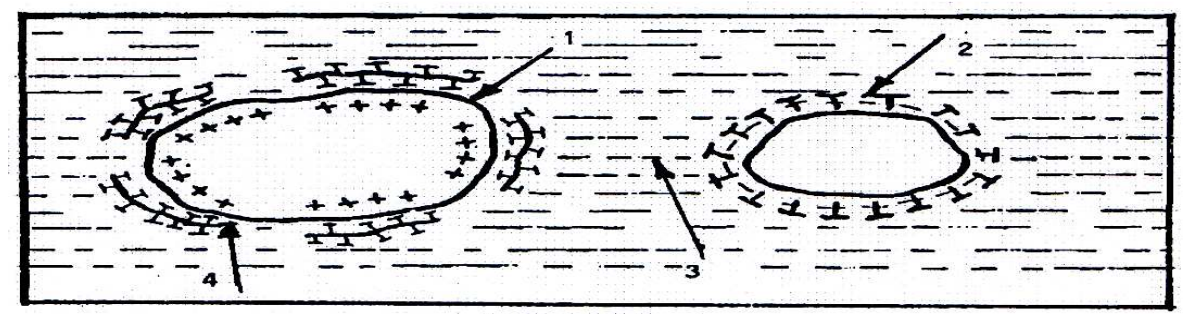

Fig. 3: Mechanism effect of organic elements on the cement particles.

1-Cement particle, 2- Bubble of drawing air, 3-Water,

4- Admixture molecule with negative charge on the surface



Fig. 4: Effect of organic admixture on formation space and coagulate structure of cement material

1-Cement particle, 2-Admixture molecule, 3-Bubble of drawing air, 4-Zone of reducing effect of double layer of non polar chain of admixture molecule, 5-Anode group, 6- Non polar radical

Investigations of using chemical admixtures for the improvement of concrete properties in Egypt show that, they are not sufficient and the elements of these admixtures are foreign by the origin and not produced here. Therefore, the system of our constructions completely depends on the foreign firms. So, these elements become deficient and expensive. These are the actual problems for business and system of Egyptian industries. It is known that, the organic materials have not the solubility with water. So, in this research the solubility of these elements with water was achieved by using calcium oxide and superplasticizers such as "BVF" and "PVS". Investigations about using complex organic admixtures, which contain in their composition alkali wastes from oil industries, such as (LSM, CLSM, SM-B, SM-R) for the improvement of cement materials properties were carried out [16-18]. But, the mechanism effect of organic admixtures, containing alkali industrial wastes from oil and cellulose paper industries, on the resistance of concrete elements against sulfate and chloride attack has not been enough studied.

So, this paper focuses on the experimental studies about the possibility of producing new chemical organic admixtures containing in their compositions alkali wastes from oil and cellulose paper industries, which represent cheaper material in our country (type SM-S, SM-O \& CM-B). And then study their mechanism effect on the compressive strength and durability of normal strength concrete specimens of about $250-350 \mathrm{~kg} / \mathrm{cm}^{2}$, which were subjected to different concentrations of sulfate and 
magnesium attack and different cycles of durability test. Experimental program consists of testing 384 cubic concrete specimens to propose the best-suggested admixture effect on their compressive strength and durability under these aggressive environmental conditions.

\section{2- EXPERIMENTAL PROGRAM}

The main aim of this program is to investigate experimentally the compressive strength and durability of different groups of normal strength concrete specimens modified with these new types of organic admixtures and exposed to different concentrations of sulfate solutions and different cycles of durability test. The experimental approaches in this study consist of testing standard cubic concrete specimens under static load. The main variables studied were:

- three different types of suggested organic admixtures, which were fabricated in the laboratory and contained in their composition alkali wastes of oil and cellulose paper industries (type: SM-S, CM-B \& SM-O).

- three different concentrations of surrounded sulfate solutions $\left(\mathrm{Na}_{2} \mathrm{SO}_{4}+\mathrm{MgSO}_{4}\right)$.

- four different cycles of durability test $(15,25,40 \& 50$ cycles).

All groups of concrete specimens (384 cubes), with and without admixtures, were identical in size, $15 \times 15 \times 15 \mathrm{cms}$. Specimens were cast and hardened in fresh water conditions until 28-days. After that, some of them (135 cubes) were immersed and hardened in different concentrations of sodium and magnesium sulfate solutions for a period of 7 months. Concrete specimens were divided into three groups depending on the amount of concentration of sulfate solutions. Each group consist of 45 concrete cubes depending on the type of fabricated organic admixtures (SM-S, CM-B \& SM-O) and control plasticizing admixture (type $\mathrm{DM}_{2}$ ). The first group (Group A) of cubes was immersed in $\left(2 \% \mathrm{Na}_{2} \mathrm{SO}_{4}+1 \% \mathrm{MgSO}_{4}\right)$, the second group (Group B) was immersed in $\left(4 \% \mathrm{Na}_{2} \mathrm{SO}_{4}+2 \% \mathrm{MgSO}_{4}\right)$. But, the third group (Group C) was immersed in $\left(6 \% \mathrm{Na}_{2} \mathrm{SO}_{4}+3 \% \mathrm{MgSO}_{4}\right)$ for a period of 7 months. But, the other cubic specimens (189 cubes) were hardened in fresh water for a period of 7 months. The retained cubes (60 cubes) were subjected to four cycles of durability test. Then, some of all groups of cubes were tested under axial compression load. Microscopic analyses were carried on mortar specimens $(2 \times 2 \times 2 \mathrm{~cm})$ before and after durability test.

\section{3- Materials}

\subsection{Technique Of Preparing And Producing The Suggested Admixtures}

The experimental technique for preparing and producing the suggested organic admixtures (SM-S, CM-B \& SM-O) were carried out by the method explained in the previous works $[15,16]$. The following materials were used for preparing and producing the suggested organic admixtures: secondary products and alkali wastes (liquid solution, $\mathrm{pH}=9.5$ and concentration $=15 \%$ ) of vegetable oil and cellulose paper industries, Calcium oxide "CaO" in a shape of powder, Superplasticizers "Addicrete BVF", \& “ Addicrete PVS ", and water.

The experimental method of preparing the suggested admixtures consists of combination of the selected compositions of their elements in a mixer with compulsory 
effect (volume $=12$ liters, speed $=300$ r.p.m.) until obtaining a homogeneous solutions without sedimentation. The combination of alkali wastes of oil and cellulose paper industries with water was achieved by adding dry grind lime $(\mathrm{CaO})$ or Superplasticizers with small doses to the mixture in the mixer. The effect of composition and parameters of combination of different elements on the quality of the suggested admixtures was carried out by using the previous explained methods [15-17]. The composition and correlation of components of the proposed admixtures by weight from their solid particles are shown in Table 1.

Table 1: Composition and correlation of components of the organic admixtures.

\begin{tabular}{|c|c|c|}
\hline $\begin{array}{l}\text { Type of } \\
\text { admixture }\end{array}$ & Components of the admixture & $\begin{array}{l}\text { Correlation of } \\
\text { components, } \% \text { by } \\
\text { weight }\end{array}$ \\
\hline $\begin{array}{c}\text { "SM-O" } \\
\text { (Suggested ) }\end{array}$ & $\begin{array}{l}\text { 1-Alkali wastes of vegetable oil industries } \\
\text { (brown liquid solution, } \mathrm{pH}=9.5 \& \mathrm{C}=15 \% \text { ), } \\
\text { 2-Calcium oxide "CaO", and } \\
\text { 3- Water }\end{array}$ & $\begin{array}{c}8.00 \\
0.62 \\
91.38\end{array}$ \\
\hline $\begin{array}{c}\text { "SM-S" } \\
\text { (Suggested ) }\end{array}$ & $\begin{array}{l}\text { 1-Alkali wastes of vegetable oil industries } \\
\text { (brown liquid solution, } \mathrm{pH}=9.5 \& \mathrm{C}=15 \% \text { ), } \\
\text { 2-calcium oxide "CaO" } \\
\text { 3- Superplasticizer "PVS “, and } \\
\text { 4-Water }\end{array}$ & $\begin{array}{c}8.00 \\
0.67 \\
1.87 \\
89.46\end{array}$ \\
\hline $\begin{array}{c}\text { “CM-B“" } \\
\text { (suggested ) }\end{array}$ & $\begin{array}{l}\text { 1-Alkali wastes of cellulose paper } \\
\text { industries (liquid solution } \mathrm{pH}=9 \& \mathrm{C}=12 \% \text { ), } \\
\text { 2- Calcium oxide "CaO" , } \\
\text { 3-Superplasticizer "BVF ", and } \\
\text { 4-Water }\end{array}$ & $\begin{array}{l}8.00 \\
0.67 \\
1.76 \\
89.57\end{array}$ \\
\hline
\end{tabular}

The system of mixing of the proposed admixtures with the concrete mixes can be achieved as follows: the admixture, in a shape of solution or paste, with limited doses must be diluted with the required amount of water of the concrete mix. After that, the obtaining solution must be mixed with the different components of the concrete mix by using useful method of preparation of concrete mixes. It is necessary to notice that, temperature of the required water for concrete mixes should not be smaller than $20^{\circ} \mathrm{c}$ to prevent the appearance of sedimentation of organic elements.

Compatibility of initial components of any admixture represents an important requirement for its chemical characteristics. Compatibility of admixture components means their correlation in the ability of producing additional chemical reactions and their common effect on the cement materials properties. Investigations of compatibility of initial components of the suggested admixtures were studied by using the method of spectroscope $[15,16]$. By the comparison of the obtaining results from spectroscope for each component of the suggested admixtures with the tables of absorption, it was determined that, the infrared spectrum for all components of admixtures represented sum of spectrum of their individual components. So, the appearance of chemical bond reaction between initial components of the suggested organic admixtures has not occurred. 


\subsection{Chemical Analysis Of Alkali Industrial Wastes}

Alkali wastes from cellulose paper industries consist of lime clay and clay from industrial sewage station. Chemical analysis of alkali wastes from cellulose paper industries (type lime clay and clay of industrial sewage station) was carried out and the results are shown in Tables $2,3$.

Table 2: Chemical analysis of alkali wastes (type: Lime clay) from cellulose paper industries.

\begin{tabular}{|c|c|c|c|c|c|c|c|c|}
\hline Components & $\begin{array}{c}\text { Silica }+ \\
\text { non-soluble } \\
\text { materials }\end{array}$ & $\begin{array}{c}\text { Combined } \\
\text { Oxides }\end{array}$ & $\begin{array}{c}\text { Sodium } \\
\text { hydroxide } \\
\mathrm{Na}(\mathrm{OH})\end{array}$ & $\begin{array}{c}\text { Sodium } \\
\text { sulfide } \\
\mathrm{Na}_{2} \mathrm{~S}\end{array}$ & $\begin{array}{c}\text { Sodium } \\
\text { carbonate } \\
\mathrm{Na}_{2}\left(\mathrm{CO}_{3}\right)\end{array}$ & $\begin{array}{c}\text { Sodium } \\
\text { sulfate } \\
\mathrm{Na}_{2}\left(\mathrm{SO}_{4}\right)\end{array}$ & $\begin{array}{c}\text { Calcium } \\
\text { carbonate } \\
\mathrm{Ca}\left(\mathrm{CO}_{3}\right)\end{array}$ & Unknowns \\
\hline Correlation, $\%$ & 7.27 & 1.05 & 0.481 & 0.039 & 0.848 & 0.243 & 89.982 & 0.087 \\
\hline
\end{tabular}

Table 3: Chemical analysis of alkali wastes (type: clay of industrial sewage station) from cellulose paper industries.

\begin{tabular}{|c|c|c|c|c|}
\hline Components & Organic Materials & Azot & Phosphates & Ashes \\
\hline Correlation, $\%$ & 91.252 & 2.1 & 0.389 & 6.259 \\
\hline
\end{tabular}

\subsection{Normal Strength Concrete}

After obtaining optimum dose of each admixture, at which occurred maximum compressive strength, concrete mixes were used to produce normal strength concrete having 28-days cubic compressive strength of $250-350 \mathrm{~kg} / \mathrm{cm}^{2}$. The influence of the value of optimum dose and type of each admixture on the properties of concrete mixes is shown in Table 4.

Ordinary Portland cement of specific gravity 3.2 was used (Assiut cement). Coarse aggregate used was $20 \mathrm{~mm}$ maximum nominal size and fineness modulus 7.12. Local natural sand of fineness modulus 2.35 was used as a fine aggregate.

Table 4: Details and properties of concrete mixes at optimum dose of the suggested admixtures.

\begin{tabular}{|c|c|c|c|c|c|c|c|c|}
\hline \multirow{2}{*}{$\begin{array}{l}\text { Mix } \\
\text { No. }\end{array}$} & \multicolumn{3}{|c|}{$\begin{array}{c}\text { Mix components, } \\
\mathrm{Kg} / \mathrm{m}^{3} \\
\end{array}$} & \multicolumn{2}{|c|}{ Suggested Admixtures } & \multirow[b]{2}{*}{$\mathrm{W} / \mathrm{c}$} & \multirow[b]{2}{*}{$\begin{array}{l}\text { Slump, } \\
\mathrm{cm}\end{array}$} & \multirow{2}{*}{$\begin{array}{l}\mathrm{F}_{\mathrm{c}} \\
\mathrm{kg} / \mathrm{cm}^{2} \\
\text { at } 28 \\
\text { days }\end{array}$} \\
\hline & $\mathrm{C}$ & S & G & Type & $\begin{array}{c}\text { Optimum dose, } \\
\% \text { by weight of } \\
\text { cement }\end{array}$ & & & \\
\hline 1 & 350 & 671 & 1283 & control & 0.00 & 0.440 & 5.0 & 277 \\
\hline 2 & 350 & 688 & 1316 & DM2 & 0.25 & 0.385 & 5.0 & 420 \\
\hline 3 & 350 & 680 & 1300 & SM-S & 0.25 & 0.410 & 5.0 & 320 \\
\hline 4 & 350 & 679 & 1298 & CM-B & 0.25 & 0.415 & 5.0 & 330 \\
\hline 5 & 350 & 676 & 1292 & SM-O & 0.25 & 0.425 & 5.0 & 281 \\
\hline
\end{tabular}




\subsection{External Sulfate Solutions}

Three different concentrations of sodium sulfate " $\mathrm{Na}_{2} \mathrm{SO}_{4}$ " and magnesium sulfate " $\mathrm{MgSO}_{4}$ " solutions were used as external sulfate attack as follows:

- Group A : $2 \% \mathrm{Na}_{2} \mathrm{SO}_{4}+1 \% \mathrm{MgSO}_{4}$,- Group B : $4 \% \mathrm{Na}_{2} \mathrm{SO}_{4}+2 \% \mathrm{MgSO}_{4}$,

- Group C: $6 \% \mathrm{Na}_{2} \mathrm{SO}_{4}+3 \% \mathrm{MgSO}_{4}$

\subsection{Test Procedure}

Some of the concrete cubes (189 cubes) were hardened in fresh water and others (135 cubes) in different concentrations of sulfate solutions for a period of 7 months. The retained cubes (60 cubes) were subjected to durability test of different cycles $(15,25,40 \& 50$ cycles) after 28 days hardening in fresh water. Each cycle consists of 4 days: 2 days hardening in $\left(6 \% \mathrm{Na}_{2} \mathrm{SO}_{4}+3 \% \mathrm{MgSO}_{4}\right)$, one day hardening in an oven of elevated temperature up to $150^{\circ} \mathrm{c}$ and one day hardening in the laboratory conditions.

The testing machine (EMS 500-tons) was used. Each specimen was loaded axially and gradually keeping the rate of loading constant. The concrete specimens were tested under static axial compression loading after 7 months hardening in fresh water or in sulfate solutions. After durability test, concrete specimens were subjected to water absorption and compression tests. The axial load was applied gradually with an increment of 2 tons up to cracking and failure.

\section{4- RESULTS AND DISCUSSIONS}

Test results of the all-cubic concrete specimens, without admixtures and modified with the suggested admixtures, which hardened in different aggressive environmental conditions are presented in Tables 5, 6 \& 7 .

\subsection{Effect Of Type Of The Suggested Admixtures On The Properties Of Concrete Mix}

It is useful that, formation of structure, physical and mechanical properties of cement concrete depends mainly on the workability and sedimentation of the mixture. Effect of different doses of the proposed admixtures on the water- cement ratio and sedimentation index was studied for concrete mixes of constant workability represented by a constant slump of $5 \mathrm{~cm}$ of the standard cone. The experimental results were determined for different doses of the admixtures $(0.0,0.25,0.50 \& 0.75 \%$ from weight of cement) and shown in Table 5 and Fig. 5.

Obviously, water-cement ratio and sedimentation index of concrete mixes clearly decrease depending on the dose and type of the admixture. By increasing the dose of the suggested admixtures (DM2, SM-S, CM-B \& SM-O) from 0.0 to $0.75 \%$ from weight of cement, W/C decreases respectively by about 36, 30, $15 \& 7 \%$. Also, sedimentation index decreases respectively by about $32,39,40 \& 41 \%$ compared to the control mix without admixtures. This is explained by the adsorption of the organic elements on the surfaces of cement particles and filling materials (as shown in Fig. 3). This leads to appearance of absorption layers, which provide hydrodynamic greasing between cement particles and allow decreasing friction between them. So, fluidity and consistency of the cement concrete mixes increased. 
Table 5: Effect of different doses of each admixture on the properties of concrete mix and compressive strength of concrete specimens hardened in fresh water.

\begin{tabular}{|c|c|c|c|c|c|c|c|}
\hline \multirow{2}{*}{$\begin{array}{c}\text { Type of } \\
\text { Admixture, }\end{array}$} & $\begin{array}{c}\text { Dose, } \% \\
\text { by weight } \\
\text { of cement }\end{array}$ & W/C & \multirow{2}{*}{$\begin{array}{c}\text { Slump, } \\
\mathrm{cm}\end{array}$} & $\begin{array}{c}\text { Sedimentation } \\
\text { index }\end{array}$ & \multicolumn{3}{|c|}{ Compressive Strength, $\mathrm{kg} / \mathrm{cm}^{2}$} \\
\cline { 6 - 9 } & & & & 7 days & 28 days & 210 days \\
\hline Control & 0.0 & 0.440 & 5 & 6.80 & 223 & 277 & 289 \\
\hline DM2, & 0.25 & 0.385 & & 5.10 & 344 & 420 & 427 \\
(Control) & 0.50 & 0.330 & 5 & 4.73 & 362 & 430 & 420 \\
& 0.75 & 0.280 & & 4.60 & 306 & 367 & 325 \\
\hline SM-S, & 0.25 & 0.410 & & 4.70 & 263 & 320 & 356 \\
(Suggested) & 0.50 & 0.355 & 5 & 4.40 & 288 & 324 & 344 \\
& 0.75 & 0.310 & & 4.15 & 307 & 338 & 339 \\
\hline CM-B & 0.25 & 0.415 & & 4.50 & 276 & 330 & 347 \\
(Suggested) & 0.50 & 0.403 & 5 & 4.30 & 208 & 271 & 296 \\
& 0.75 & 0.375 & & 4.08 & 206 & 267 & 279 \\
\hline SM-O, & 0.25 & 0.425 & & 4.64 & 208 & 281 & 341 \\
(Suggested) & 0.50 & 0.420 & 5 & 4.35 & 184 & 245 & 305 \\
& 0.75 & 0.410 & & 4.05 & 163 & 199 & 265 \\
\hline
\end{tabular}



Dose of Admixture, \% by weight of cement

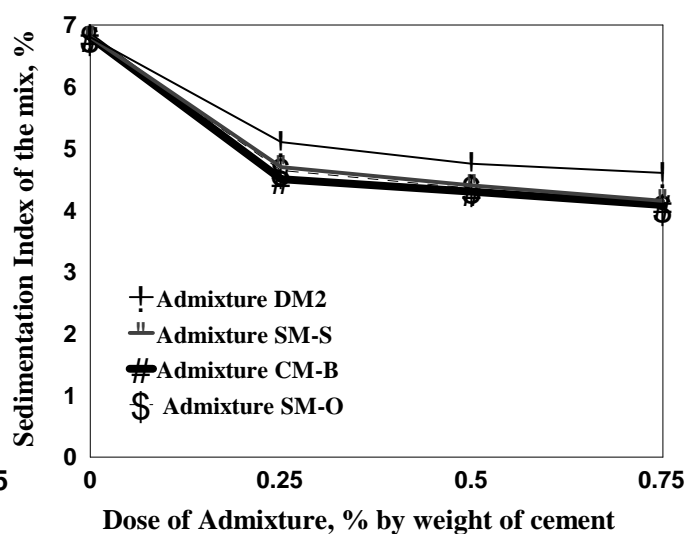

Dose of Admixture, \% by weight of cement

Fig. 5: Water cement ratio \&sedimentation of concrete mixes versus dose of admixture.

\subsection{Determination Of The Optimum Dose Of The Suggested Admixtures}

Effect of different doses of the proposed admixtures on the compressive strength of concrete specimens having the same workability and hardened in fresh water at different ages was studied. Optimum dose of each admixture, at which occurred maximum values of compressive strength was determined and the results are shown in Fig. 6. 

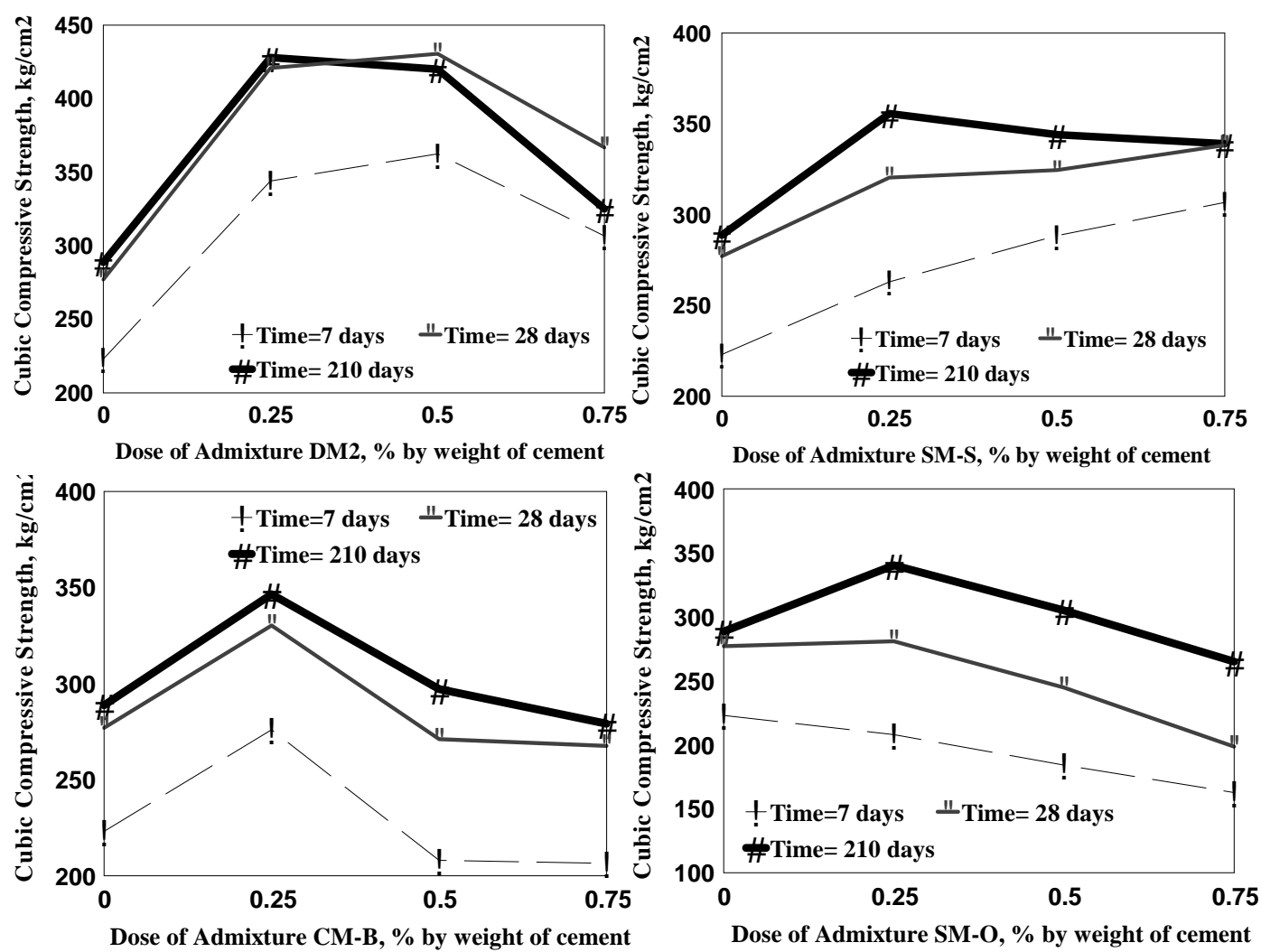

Fig. 6: Effect of different doses of each admixture on the cubic compressive strength of concrete specimens hardening in fresh water.

Obviously, optimum dose of the control and suggested admixtures equals $0.25 \%$ from weight of cement. At which, compressive strength of concrete specimens modified with the organic admixtures (SM-S, CM-B \& SM-O) at age of 7 months increased respectively by about $23,20 \& 18 \%$. But, it increased by about $48 \%$ for concrete specimens modified with the control plasticizing admixture (DM2) compared to the control specimens without admixtures.

\subsection{Compressive Strength Of Concrete Specimens Exposed To Sulfate Solutions}

Cubic compressive strength of all types of concrete containing optimum doses of the suggested admixtures and hardened in fresh water and in different concentrations of sulfate solutions until 7 months are shown in Tables 5 \& 6 and Fig. 7.

Obviously, the organic admixtures (type SM-S, SM-O, \&CM-B), containing in their compositions alkali wastes from oil and cellulose paper industries, have a good effect on increasing compressive strength of concrete hardening in these aggressive conditions compared to the control specimens. Respectively, they increase it by about 
$35,29, \& 39 \%$ for specimens immersed in $\left(2 \% \mathrm{Na}_{2} \mathrm{SO}_{4}+1 \% \mathrm{MgSO}_{4}\right)$, by about 52 , $45, \& 49 \%$ for specimens immersed in $\left(4 \% \mathrm{Na}_{2} \mathrm{SO}_{4}+2 \% M g S O_{4}\right)$, and by about 46 , $38, \& 37 \%$ for specimens immersed in $\left(6 \% \mathrm{Na}_{2} \mathrm{SO}_{4}+3 \% \mathrm{MgSO}_{4}\right)$ compared to the control specimens without admixtures. It is necessary to notice that, these admixtures also have a good effect on increasing compressive strength of concrete specimens compared to that modified with the known plasticizing admixtures "DM2" and hardened in the same conditions.

Table 6: Effect of optimum dose of each admixture on the compressive strength of concrete specimens hardened in sodium and magnesium sulfate solutions.

\begin{tabular}{|c|c|c|c|c|c|c|c|c|c|c|}
\hline \multirow{3}{*}{$\begin{array}{c}\text { Type of } \\
\text { Admixture, }\end{array}$} & \multirow{3}{*}{$\begin{array}{l}\text { Optimum } \\
\text { dose, } \% \\
\text { By weight } \\
\text { of cement }\end{array}$} & \multicolumn{9}{|c|}{ Compressive Strength, $\mathrm{kg} / \mathrm{cm}^{2}$ for different groups } \\
\hline & & \multicolumn{3}{|c|}{$\begin{array}{l}\text { (A):2\%" } \mathrm{Na}_{2} \mathrm{SO}_{4} " \\
+1 \% " \mathrm{MgSO}_{4} "\end{array}$} & \multicolumn{3}{|c|}{$\begin{array}{l}\text { (B): } 4 \% " \mathrm{Na}_{2} \mathrm{SO}_{4} " \\
+2 \% " \mathrm{MgSO}_{4} "\end{array}$} & \multicolumn{3}{|c|}{$\begin{array}{l}\text { (C):6\% "Na } \mathrm{SO}_{4} " \\
+3 \% \text { " } \mathrm{MgSO}_{4} "\end{array}$} \\
\hline & & 7 days & 28 days & $\begin{array}{c}210 \\
\text { days }\end{array}$ & 7 days & 28 days & $\begin{array}{l}210 \\
\text { days }\end{array}$ & 7 days & 28 days & $\begin{array}{l}210 \\
\text { days }\end{array}$ \\
\hline Control & 0.0 & 258 & 285 & 275 & 250 & 275 & 263 & 240 & 267 & 248 \\
\hline $\begin{array}{l}\text { DM2, } \\
\text { (Control) }\end{array}$ & 0.25 & 390 & 395 & 364 & 380 & 369 & 358 & 380 & 360 & 338 \\
\hline $\begin{array}{c}\text { SM-S, } \\
\text { (Suggested) }\end{array}$ & 0.25 & 320 & 368 & 372 & 336 & 387 & 400 & 350 & 373 & 382 \\
\hline $\begin{array}{c}\text { CM-B } \\
\text { (Suggested) }\end{array}$ & 0.25 & 327 & 376 & 381 & 339 & 384 & 393 & 348 & 350 & 354 \\
\hline $\begin{array}{c}\text { SM-O, } \\
\text { (Suggested) }\end{array}$ & 0.25 & 269 & 310 & 354 & 327 & 337 & 355 & 339 & 347 & 356 \\
\hline
\end{tabular}

(a)

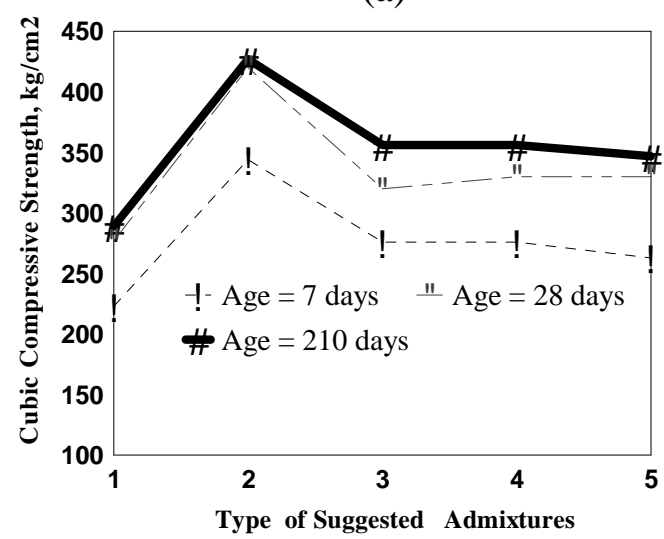

(b)

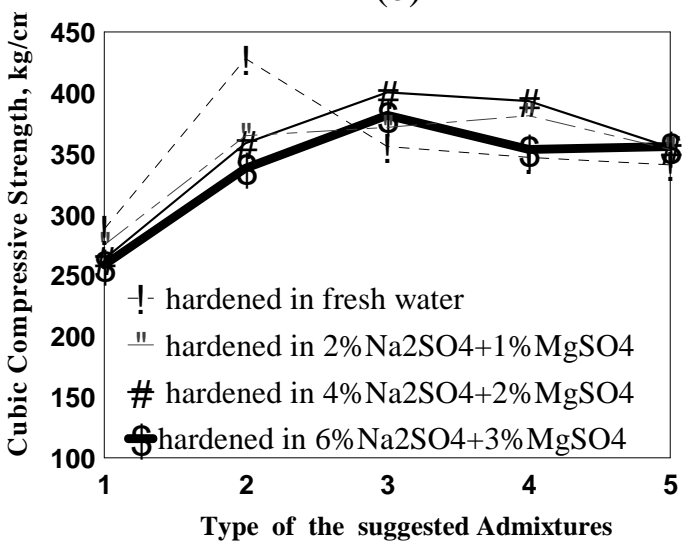

Fig. 7: Cubic compressive of different groups of concrete specimens as affected by the optimum dose of each type of the suggested admixtures.

(a) Specimens hardened in fresh water, (b) Specimens hardened in $\left(\mathrm{Na}_{2} \mathrm{SO}_{4}+\mathrm{MgSO}_{4}\right)$

1) Control specimens without admixtures, 2) Specimens with control admixture DM2,

3) Specimens with admixture SM-S, 4) Specimens with organic admixture CM-B,

5) Specimens with organic admixture SM-O 
Obviously, the suggested admixtures (type SM-S, SM-O, \&CM-B) increased compressive strength of concrete specimens hardened in these aggressive conditions after 7 months by about $46,38, \& 37 \%$ respectively compared to the control specimens hardened in the same conditions. Also, these admixtures have a good effect than the plasticizing admixture (DM2). This may be explained by the effect of organic elements, from alkali wastes of oil and cellulose paper industries, on forming adsorption organic layers around cement minerals, which have the ability of keeping amount of cement minerals $\left(\mathrm{C}_{2} \mathrm{~S}+\mathrm{C}_{3} \mathrm{~S}\right)$ without hydration for a period of time. This was clear from the reduction of the compressive strength of specimens modified with these admixtures in the early periods of hardening until 7-days. After a period of hardening in sulfate solutions, these organic layers destroyed and the non-hydrated cement minerals began to hydrate in the presence of water. So, an additional amount of crystalline hydrated phase (type calcium silicate hydrate C-S-H gel) was produced and filled the internal pores in the concrete specimens. Consequently, regulation of microstructure formation occurred, denser and homogeneous concrete has produced. Therefore, compressive strength of organic concrete increased and its mechanical properties improved in these aggressive conditions.

According to that, compressive strength values of concrete specimens containing these admixtures and hardened in these aggressive environmental conditions were plotted versus age of concrete (as shown in Fig. 8). As the concentration of sulfate solutions increases from $3 \%$ to $9 \%$, concrete compressive strength of control specimens, without admixtures \& with control admixture DM2, decreased by about $11 \%$ \& $21 \%$ respectively compared to the same specimens hardened in fresh water. But, for specimens modified with the suggested organic admixtures, it increased by a value ranged from $4 \%$ to $7 \%$ depending on the type of admixtures and compared to the same type of specimens hardened in fresh water.

(a)

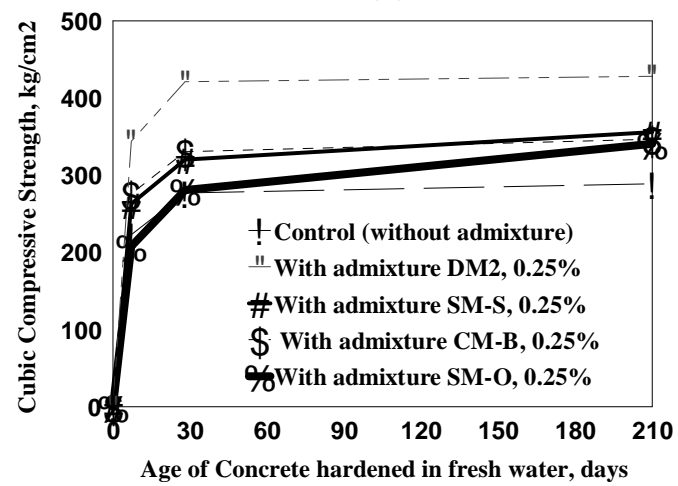

(b)

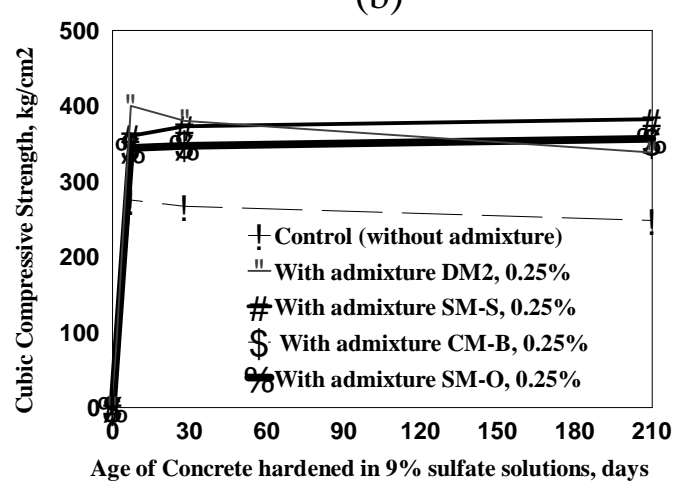

Fig. 8: Cubic compressive strength of different groups of concrete specimens versus age of concrete as affected by each type of the suggested admixtures.

a) Specimens hardened in fresh water, b) Specimens hardened in sulfate solutions $\left(6 \% \mathrm{Na}_{2} \mathrm{SO}_{4}+3 \% \mathrm{MgSO}_{4}\right)$ 


\subsection{Compressive Strength Of Concrete Specimens Exposed To Durability Tests}

The most important factors affecting durability of concrete elements hardened in aggressive environmental conditions represent compressive strength, water and moisture absorption. So, the effect of optimum dose of each admixture on the compressive strength and water absorption of concrete specimens before and after different cycles of durability tests was investigated with the comparison of the control specimens. The results were determined and shown in Table 7 and Fig. 9.

\subsubsection{Concrete specimens exposed to 15 cycles of durability tests}

Compressive strength of concrete specimens with and without admixtures, which exposed to 15 cycles of durability test was determined and the results are shown in Fig. 9a. Obviously, compressive strength of concrete specimens containing admixtures (SM-S \& CM-B) increased by about $7 \%$ after this cycles of durability test compared with the same type of specimens before durability test. But, control specimens without admixtures and with the control admixture (DM2) showed a large decrease of their compressive strength by about $11 \%$ \& $23 \%$ respectively compared with the same specimens before this cycles of durability test. Also, specimens modified with the suggested admixture (SM-O) showed a very small decrease of their compressive strength by about $1 \%$ only compared with the same specimens before this cycles of durability test. It is necessary to notice that the suggested admixtures (DM2, SM-S, CM-B \&SM-O) increased compressive strength and durability index of concrete specimens after 15 cycles of durability test by about $27,48,44 \& 32 \%$, respectively compared to the control specimens without admixtures.

Table 7: Effect of optimum dose of each admixture on the compressive strength of concrete specimens exposed to different cycles of durability tests.

\begin{tabular}{|c|c|c|c|c|c|c|c|}
\hline \multirow{3}{*}{$\begin{array}{c}\text { Type of } \\
\text { Admixture, }\end{array}$} & \multirow{3}{*}{$\begin{array}{l}\text { Optimum } \\
\text { dose, } \% \text { by } \\
\text { weight of } \\
\text { cement }\end{array}$} & \multirow{3}{*}{$\mathrm{W} / \mathrm{C}$} & \multicolumn{5}{|c|}{ Compressive Strength, $\mathrm{kg} / \mathrm{cm}^{2}$} \\
\hline & & & \multirow{2}{*}{$\begin{array}{c}\text { Before } \\
\text { durability }\end{array}$} & \multicolumn{4}{|c|}{ After durability } \\
\hline & & & & 15 cycles & 25 cycles & 40 cycles & 50 cycles \\
\hline Control & 0.0 & 0.440 & & $\frac{257}{0.89}$ & $\frac{242}{0.84}$ & $\frac{205}{0.71}$ & $\frac{185}{0.64}$ \\
\hline $\begin{array}{c}\text { DM2, } \\
\text { (Control) }\end{array}$ & 0.25 & 0.385 & $\frac{428}{1.00}$ & $\frac{328}{0.77}$ & $\frac{285}{0.67}$ & $\frac{235}{0.55}$ & $\frac{220}{0.51}$ \\
\hline $\begin{array}{c}\text { SM-S, } \\
\text { (Suggested) }\end{array}$ & 0.25 & 0.410 & $\frac{356}{1.00}$ & $\frac{381}{1.07}$ & $\frac{375}{1.05}$ & $\frac{350}{0.98}$ & $\frac{345}{0.97}$ \\
\hline $\begin{array}{c}\text { CM-B } \\
\text { (Suggested) }\end{array}$ & 0.25 & 0.415 & $\frac{347}{1.00}$ & $\frac{371}{1.07}$ & $\frac{367}{1.06}$ & $\underline{345}$ & $\underline{340}$ \\
\hline $\begin{array}{c}\text { SM-O, } \\
\text { (Suggested) }\end{array}$ & 0.25 & 0.425 & $\frac{341}{1.00}$ & $\underline{338}$ & $\underline{335}$ & $\underline{330}$ & $\underline{326}$ \\
\hline
\end{tabular}



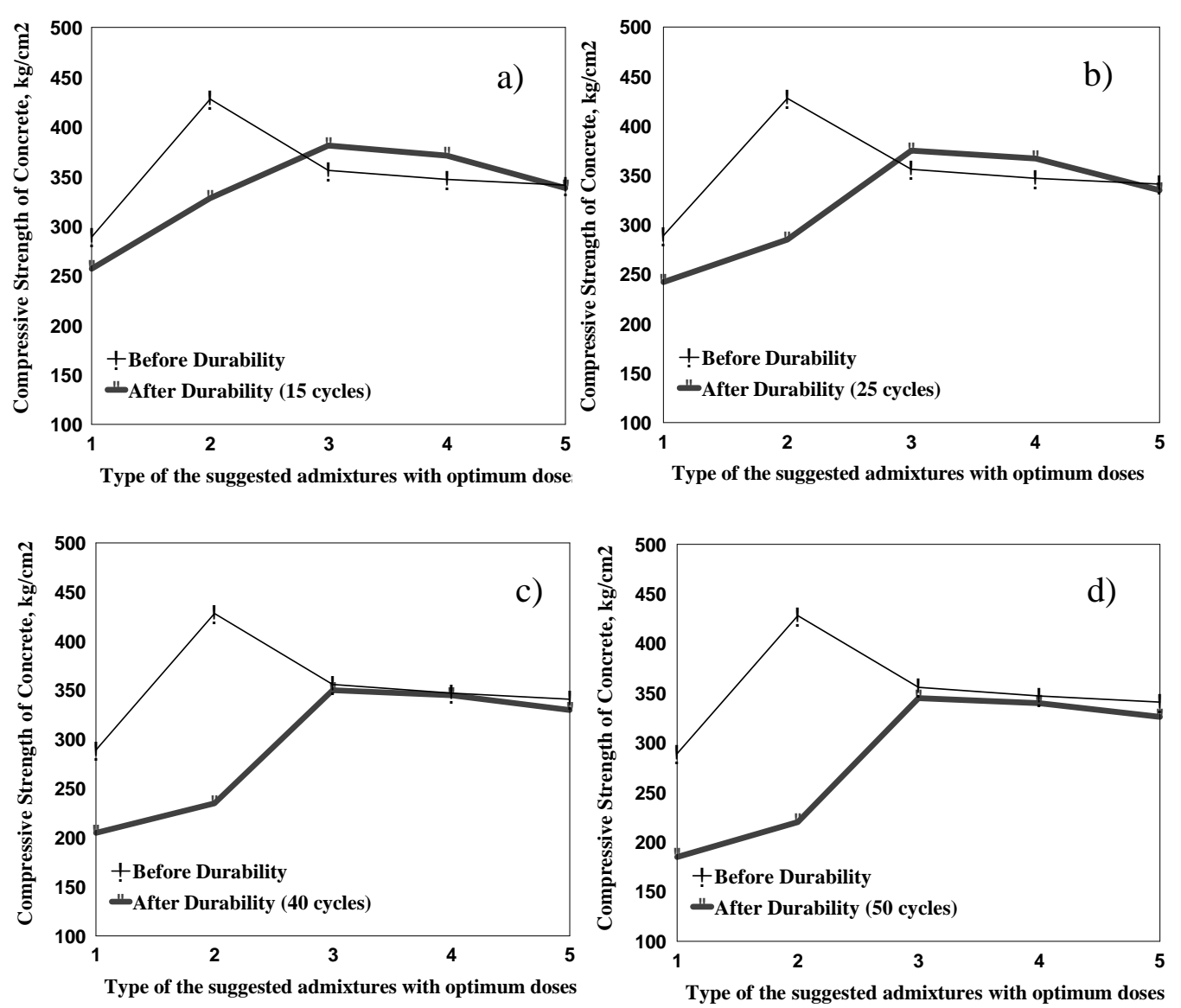

Fig. 9: Cubic compressive strength of concrete specimens versus type of the suggested admixtures as affected by different cycles of durability tests

1) Control specimens without admixtures, 2) Specimens with control admixture DM2,

3) Specimens with admixture SM-S, 4) Specimens with organic admixture CM-B,

5) Specimens with organic admixture SM-O,

\subsubsection{Concrete specimens exposed to 25 cycles of durability tests}

Compressive strength of concrete specimens with and without admixtures, which exposed to 25 cycles of durability test was determined and the results are shown in Fig. 9b. Obviously, compressive strength of concrete specimens containing admixtures (SM-S \& CM-B) increased by about $5 \& 6 \%$ respectively after these cycles of durability test compared with the same type of specimens before durability test. But, control specimens without admixtures and with the control admixture (DM2) showed a large decrease of their compressive strength by about $16 \% \& 33 \%$ respectively compared with the same specimens before this cycles of durability test.

Also, specimens modified with the suggested admixture (SM-O) showed a very small decrease of their compressive strength by about $2 \%$ only compared with the same specimens before this cycles of durability test. It is necessary to notice that the 
suggested admixtures (DM2, SM-S, CM-B \&SM-O) increased compressive strength and durability index of concrete specimens after 25 cycles of durability test by about $18,55,52 \& 38 \%$ respectively compared to the control specimens without admixtures.

\subsubsection{Concrete specimens exposed to $\mathbf{4 0}$ cycles of durability tests}

Compressive strength of concrete specimens with and without admixtures, which exposed to 40 cycles of durability test was determined and the results are shown in Fig. 9c. Obviously, control specimens without admixtures and with the control admixture (DM2) showed a large decrease of their compressive strength by about $29 \%$ $\& 45 \%$ respectively compared with the same specimens before this cycles of durability test. But, specimens modified with the suggested admixture (SM-S, CM-B \&SM-O) showed respectively a very small decrease of their compressive strength by about 2,1 \& $3 \%$ only compared with the same specimens before this cycles of durability test. It is necessary to notice that the suggested admixtures (DM2, SM-S, CM-B \&SM-O) increased compressive strength and durability index of concrete specimens after 40 cycles of durability test by about $15,71,68 \& 61 \%$ respectively compared to the control specimens without admixtures. The suggested admixtures showed a better influence compared to the control plasticizing admixtureDM2.

\subsubsection{Concrete specimens exposed to $\mathbf{5 0}$ cycles of durability tests}

Compressive strength of concrete specimens with and without admixtures, which exposed to 50 cycles of durability test was determined and the results are shown in Fig. 9d. Obviously, control specimens without admixtures and with the control admixture (DM2) showed a large decrease of their compressive strength by about $36 \%$ $\& 49 \%$ respectively compared with the same specimens before this cycles of durability test. But, specimens modified with the suggested admixture (SM-S, CM-B \&SM-O) showed respectively a very small decrease of their compressive strength by about 3,2 \& $4 \%$ only compared with the same specimens before this cycles of durability test. It is necessary to notice that the suggested admixtures (DM2, SM-S, CM-B \&SM-O) increased compressive strength and durability index of concrete specimens after 50 cycles of durability test by about $19,86,84 \& 76 \%$ respectively compared to the control specimens without admixtures. The suggested admixtures showed a better influence compared to the control plasticizing admixtureDM2.

This may be explained by the effect of organic elements, from alkali wastes of oil and cellulose paper industries, on forming adsorption organic layers around cement minerals, which have the ability of keeping amount of cement minerals $\left(\mathrm{C}_{2} \mathrm{~S}+\mathrm{C}_{3} \mathrm{~S}\right)$ without hydration for a period of time. After a period of hardening in sulfate solutions and elevated temperatures up to $150^{\circ} \mathrm{c}$, these organic layers were damaged and dissolved gradually. So, the non-hydrated cement minerals began to hydrate in the presence of water and temperature and an additional amount of crystalline hydrated phase (type calcium silicate hydrate C-S-H gel) was produced and filled the internal pores in the concrete specimens. Consequently, regulation of microstructure formation occurred, denser and homogeneous concrete produced. Therefore, compressive strength of organic concrete increased and its mechanical properties improved after these cycles of durability tests. 


\subsection{Water Absorption And Moisture Adsorption Of Concrete Specimens Exposed To Different Cycles Of Durability Tests}

Effect of optimum dose of each admixture on the water absorption and moisture adsorption of concrete specimens before and after different cycles of durability tests was investigated with the comparison of the control specimens. The results were determined and shown in Tables 8 \& 9 .

Table 8: Effect of optimum dose of each admixture on the water absorption of concrete specimens exposed to different cycles of durability tests.

\begin{tabular}{|c|c|c|c|c|c|c|c|}
\hline \multirow{3}{*}{$\begin{array}{c}\text { Type of } \\
\text { Admixture }\end{array}$} & \multirow{3}{*}{$\begin{array}{l}\text { Optimum } \\
\text { dose, \% by } \\
\text { weight of } \\
\text { cement }\end{array}$} & \multirow{3}{*}{$\mathrm{W} / \mathrm{C}$} & \multicolumn{5}{|c|}{ Water absorption, $\%$ by weight } \\
\hline & & & \multirow{2}{*}{$\begin{array}{c}\text { Before } \\
\text { durability }\end{array}$} & \multicolumn{4}{|c|}{ After durability test } \\
\hline & & & & 15 cycles & 25 cycles & 40 cycles & 50 cycles \\
\hline \multirow{2}{*}{ Control } & \multirow{2}{*}{0.0} & \multirow{2}{*}{0.440} & $\sigma$ & 5.70 & 5.90 & 6.60 & 7.40 \\
\hline & & & 1.0 & $\overline{1.02}$ & $\overline{1.05}$ & 1.18 & 1.32 \\
\hline \multirow{2}{*}{$\begin{array}{c}\text { DM2, } \\
\text { (Control) }\end{array}$} & \multirow{2}{*}{0.25} & \multirow{2}{*}{0.385} & 4.8 & $\underline{5.10}$ & 5.60 & 6.20 & 7.00 \\
\hline & & & 1.0 & 1.06 & 1.17 & 1.29 & 1.46 \\
\hline \multirow{2}{*}{$\begin{array}{c}\text { SM-S, } \\
\text { (Suggested) }\end{array}$} & \multirow{2}{*}{0.25} & \multirow{2}{*}{0.410} & $\underline{3.2}$ & $\underline{3.00}$ & 2.80 & 6.80 & 2.95 \\
\hline & & & 1.0 & 0.94 & 0.88 & 0.88 & 0.92 \\
\hline \multirow{2}{*}{$\begin{array}{c}\text { CM-B } \\
\text { (Suggested) }\end{array}$} & \multirow{2}{*}{0.25} & \multirow{2}{*}{0.415} & 2.9 & 2.70 & 2.60 & 2.65 & $\underline{2.80}$ \\
\hline & & & $\overline{1.0}$ & 0.93 & 0.90 & 0.91 & 0.96 \\
\hline \multirow{2}{*}{$\begin{array}{c}\text { SM-O, } \\
\text { (Suggested) }\end{array}$} & \multirow{2}{*}{0.25} & \multirow[t]{2}{*}{0.425} & 3.0 & 2.80 & 2.70 & 2.60 & 2.55 \\
\hline & & & $\overline{1.0}$ & $\overline{0.93}$ & $\overline{0.90}$ & $\overline{0.87}$ & $\overline{0.85}$ \\
\hline
\end{tabular}

Table 9: Effect of optimum dose of each admixture on the moisture adsorption of concrete specimens exposed to different cycles of durability tests.

\begin{tabular}{|c|c|c|c|c|c|c|c|}
\hline \multirow{3}{*}{$\begin{array}{c}\text { Type of } \\
\text { Admixture }\end{array}$} & \multirow{3}{*}{$\begin{array}{l}\text { Optimum } \\
\text { dose, } \% \text { by } \\
\text { weight of } \\
\text { cement }\end{array}$} & \multirow{3}{*}{$\mathrm{W} / \mathrm{C}$} & \multicolumn{5}{|c|}{ Moisture adsorption, $\%$ by weight } \\
\hline & & & \multirow{2}{*}{$\begin{array}{c}\text { Before } \\
\text { durability }\end{array}$} & \multicolumn{4}{|c|}{ After durability test } \\
\hline & & & & 15 cycles & 25 cycles & 40 cycles & 50 cycles \\
\hline \multirow{2}{*}{ Control } & \multirow{2}{*}{0.0} & \multirow{2}{*}{0.440} & & $\underline{0.77}$ & $\underline{0.84}$ & $\underline{0.96}$ & $\underline{0.94}$ \\
\hline & & & 1. & $\overline{1.13}$ & $\overline{1.24}$ & $\overline{1.32}$ & 1.38 \\
\hline \multirow{2}{*}{$\begin{array}{c}\text { DM2, } \\
\text { (Control) }\end{array}$} & \multirow{2}{*}{0.25} & \multirow{2}{*}{0.385} & $\underline{0.55}$ & 0.59 & $\underline{0.74}$ & 0.82 & 0.86 \\
\hline & & & 1.00 & 1.07 & 1.34 & 1.49 & 1.56 \\
\hline \multirow{2}{*}{$\begin{array}{c}\text { SM-S, } \\
\text { (Suggested) }\end{array}$} & \multirow{2}{*}{0.25} & \multirow{2}{*}{0.410} & $\underline{0.36}$ & $\underline{0.35}$ & 0.34 & $\underline{0.36}$ & 0.37 \\
\hline & & & 1.00 & 0.97 & 0.94 & 1.00 & 1.03 \\
\hline \multirow{2}{*}{$\begin{array}{c}\text { CM-B } \\
\text { (Suggested) }\end{array}$} & \multirow{2}{*}{0.25} & \multirow{2}{*}{0.415} & $\underline{0.30}$ & $\underline{0.30}$ & 0.29 & $\underline{0.32}$ & $\underline{0.33}$ \\
\hline & & & 1.00 & 1.00 & 0.97 & 1.07 & 1.10 \\
\hline \multirow{2}{*}{$\begin{array}{c}\text { SM-O, } \\
\text { (Suggested) }\end{array}$} & \multirow{2}{*}{0.25} & \multirow{2}{*}{0.425} & 0.32 & 0.32 & 0.31 & 0.30 & 0.32 \\
\hline & & & 1.00 & 1.00 & 0.97 & 0.94 & 1.00 \\
\hline
\end{tabular}




\subsubsection{Concrete specimens exposed to $\mathbf{1 5}$ cycles of durability tests}

Obviously, concrete specimens containing admixtures (SM-S, CM-B \& SM-O) showed respectively a decrease of their water absorption of about $6,7 \& 7 \%$ and also a decrease of their moisture adsorption by about $3 \%$ after these cycles of durability test compared with the same type of specimens before durability test. But, control specimens without admixtures and with the control admixture (DM2) showed an increase of their water absorption by about $2 \& 6 \%$ and their moisture adsorption by about $13 \& 7 \%$, respectively compared with the same specimens before these cycles of durability test. It is necessary to notice that the suggested admixtures (DM2, SM-S, CM-B \&SM-O) decreased water absorption and increased durability index of concrete specimens after 15 cycles of durability test by about $11,47,53 \& 51 \%$ respectively compared to the control specimen without admixtures. Also, they decreased moisture adsorption of concrete specimens by about $33,55,61 \& 59 \%$ respectively after this type of durability.

\subsubsection{Concrete specimens exposed to 25 cycles of durability tests}

Obviously, concrete specimens containing admixtures (SM-S, CM-B \& SM-O) showed respectively a decrease of their water absorption of about $12,10 \& 10 \%$ and also a decrease of their moisture adsorption by about $6,3 \& 3 \%$ after this cycles of durability test compared with the same type of specimens before durability test. But, control specimens without admixtures and with the control admixture (DM2) showed an increase of their water absorption by about $5 \& 17 \%$ and their moisture adsorption by about $24 \& 34 \%$ respectively compared with the same specimens before these cycles of durability test. It is necessary to notice that the suggested admixtures (DM2, SM-S, CM-B \&SM-O) decreased water absorption and increased durability index of concrete specimens after 25 cycles of durability test by about $5,47,56 \& 46 \%$ respectively compared to the control specimen without admixtures. Also, they decreased misture adsorption of concrete specimens by about $12,60,66 \& 63 \%$ respectively after this type of durability.

\subsubsection{Concrete specimens exposed to $\mathbf{4 0}$ cycles of durability tests} Concrete specimens containing admixtures (SM-S, CM-B \& SM-O) showed respectively a decrease of their water absorption of about $12,9 \& 13 \%$, a decrease of their moisture adsorption by about $0 \& 6 \%$ with admixtures (SM-S\&SM-O) and an increase of their moisture adsorption by about $7 \%$ with admixture (CM-B) after these cycles of durability test compared with the same type of specimens before durability test. But, control specimens without admixtures and with the control admixture (DM2) showed an increase of their water absorption by about $18 \& 29 \%$ and their moisture adsorption by about $32 \& 49 \%$ respectively compared with the same specimens before this cycles of durability test. It is necessary to notice that the suggested admixtures (DM2, SM-S, CM-B \&SM-O) decreased water absorption and increased durability index of concrete specimens after 40 cycles of durability test by about $6,58,60 \& 61 \%$ respectively compared to the control specimen without admixtures. Also, they decreased moisture adsorption of concrete specimens by about 9, 60, 65 \& $67 \%$ respectively after this type of durability. 


\subsubsection{Concrete specimens exposed to $\mathbf{5 0}$ cycles of durability tests} Concrete specimens containing admixtures (SM-S, CM-B \& SM-O) showed respectively a decrease of their water absorption of about $8,4 \& 15 \%$, an increase of their moisture adsorption by about $3 \& 10 \%$ with admixtures (SM-S\&CM-B) and the same value of the moisture adsorption with admixture(SM-O) after these cycles of durability test compared with the same type of specimens before durability test. But, control specimens without admixtures and with the control admixture (DM2) showed an increase of their water absorption by about $32 \& 46 \%$ and their moisture adsorption by about $38 \& 56 \%$ respectively compared with the same specimens before these cycles of durability test. It is necessary to notice that the suggested admixtures (DM2, SM-S, CM-B \&SM-O) decreased water absorption and increased durability index of concrete specimens after 50 cycles of durability test by about $6,61,62 \& 66 \%$ respectively compared to the control specimen without admixtures. Also, they decreased moisture adsorption of concrete specimens by about 9, 61, $65 \& 66 \%$ respectively after this type of durability.

So, it can be said that the suggested organic admixtures showed a better and clear influence on decreasing water absorption, moisture adsorption and increasing durability index of concrete specimens exposed to different cycles of durability tests compared with the control plasticizing expensive admixture DM2. This is explained by the effectiveness of these admixtures on regulating the microstructure formation of the hardened concrete, redistribution of pores, decreasing of the macro pores and increasing the micro pores and closing the capillary pores. Consequently, water absorption and moisture adsorption decreased and durability index increased.

\subsection{Microstructure Of The Hardened Organic Concrete Specimens As Affected By Aggressive Environmental Conditions}

The mechanism effect of chemical admixtures on forming the microstructure of the hardened cement materials is closely connected with the theory of hydration and hardening of the cement minerals. Effect of optimum dose of each suggested admixture on the microstructure formation of the hardened concrete specimens in aggressive environmental conditions, before and after 50 cycles of durability tests (age = 228 days), was investigated with the comparison of the control specimens. The results were determined by using electronic microscopic analysis as shown in Figs. 10 \& 11 .

\subsubsection{Microstructure of the hardened concrete specimens in fresh water}

Figure 10 shows the effect of optimum dose of each admixture on the micro structure formation of the hardened specimens in fresh water before durability tests at age 228 days. From which it is clear that, control specimen without admixtures showed appearance of small shrinkage cracks between cement paste and filling materials, in addition to different large and small pores and its structure is non homogeneous (Fig. 10a, b). Specimen with the control admixture (DM2) showed appearance of different large and small pores without shrinkage cracks and its structure is more homogeneous than the control ones (Fig. 10c). But, specimens modified with the suggested admixtures (SM-S\& CM-B) have more dense and homogeneous structure, 
their large pores decreased and micro pores increased and they have no shrinkage cracks between cement paste and filling materials (Fig. 10d, e). Specimen with the suggested admixture (SM-O) showed appearance of different large and small pores with a very small shrinkage cracks and its structure is more homogeneous than the control (as shown in Fig. 10f).

a)

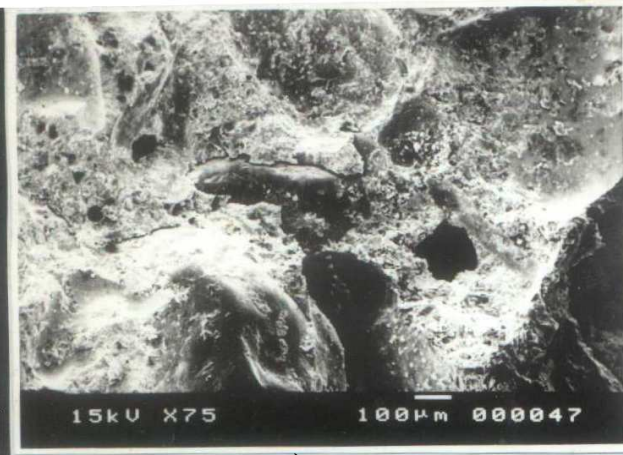

c)

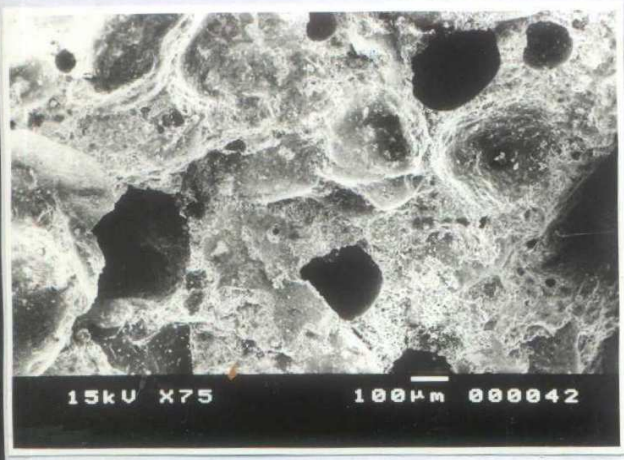

e)

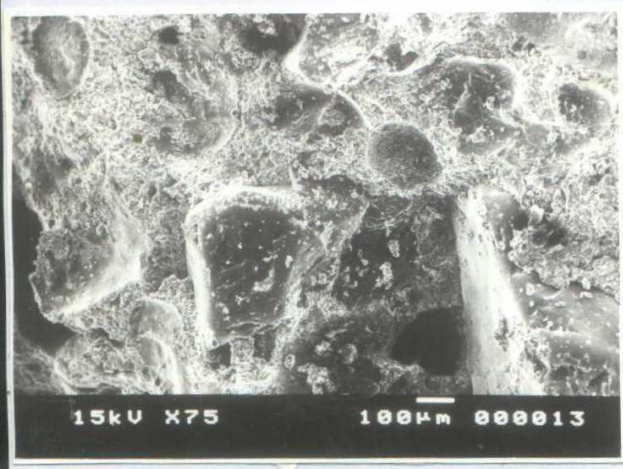

b)

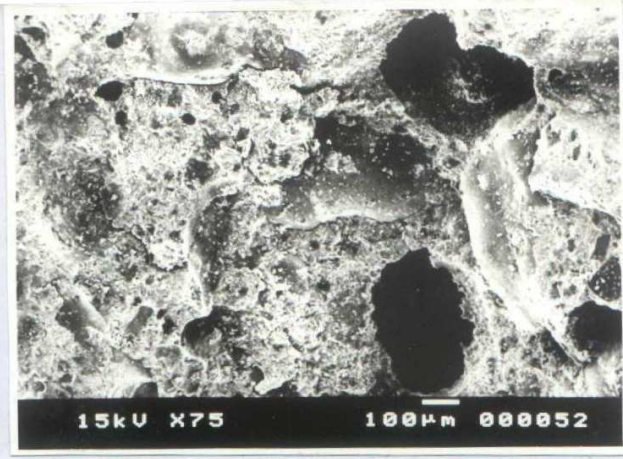

d)



f)

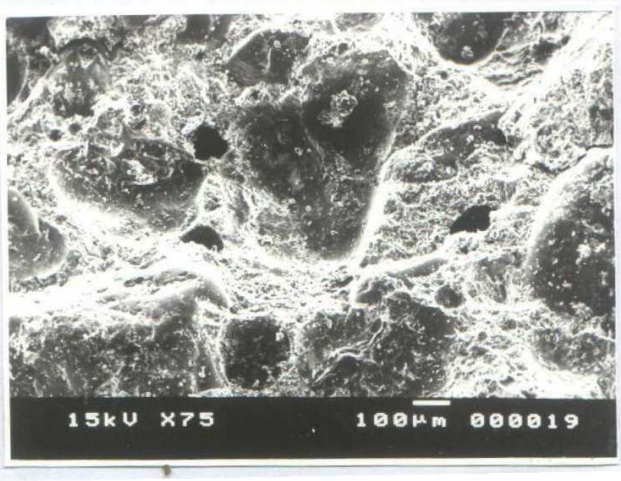

Fig. 10: Microstructure of the hardened concrete specimens before durability tests (Age $=228$ days hardening in fresh water) $\times 2000$ times
a, b) Specimens without admixtures,
c) Specimen with control admixture (DM2),

d) Specimen with admixture (SM-S),

e) Specimen with organic admixture (CM-B), f) Specimen with organic admixture (SM-O), $0.25 \%$ by weight of cement. 


\subsubsection{Microstructure of the specimens after 50 cycles of durability test}

Figure 11 shows the effect of optimum dose of each admixture on the micro structure formation of the hardened specimens in aggressive environmental conditions and after 50 cycles of durability tests at age 228 days. From which it is clear that, control specimens without admixtures showed appearance of extended wide and large open cracks between cement paste and filling materials in addition to different small shrinkage cracks in the cement paste and its structure is non homogeneous (Fig. 11a, b).

a)

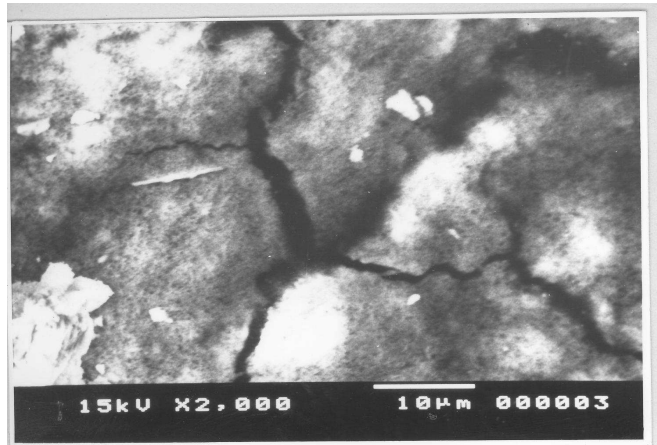

c)

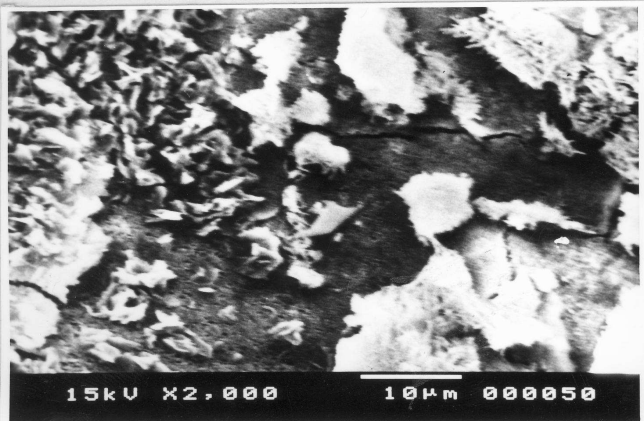

e)

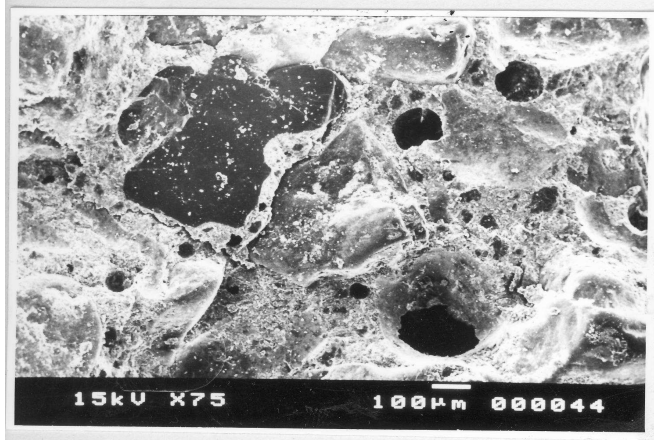

b)

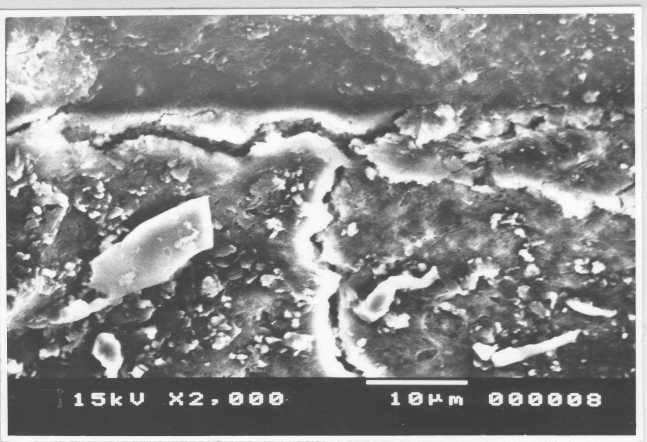

d)

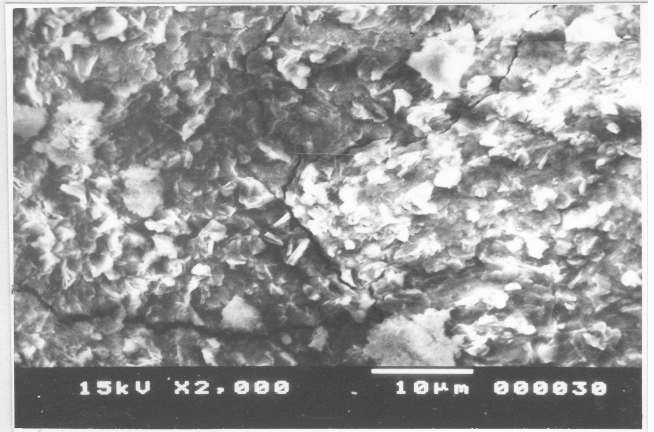

f)

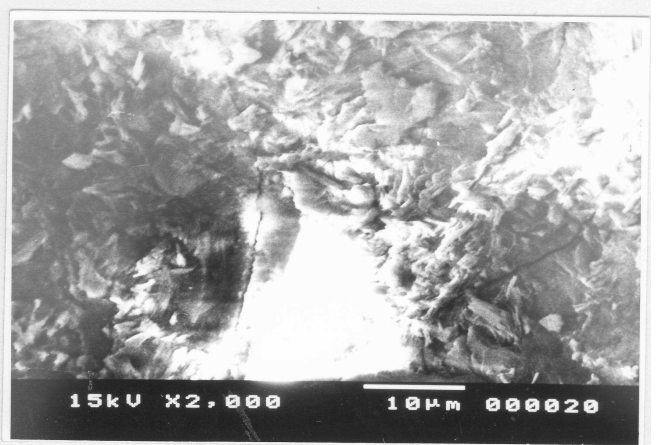

Fig. 11: Microstructure of the hardened concrete specimens after 50-cycles of durability tests (age $=228$ days hardening in aggressive conditions) $\times 2000$ times.
a, b) Specimens without admixtures,
c) Specimen with control admixture (DM2),
d) Specimen with admixture (SM-S),
e) Specimen with organic admixture (CM-B), f) Specimen with organic admixture (SM-O), $0.25 \%$ by weight of cement. 
Specimens with the control admixture (DM2) showed also appearance of different large and small cracks between cement paste and filling materials accompanied by small shrinkage cracks in the cement paste and its structure is homogeneous than the control (Fig. 11c). But, specimens modified with the suggested admixtures (SM-S, CM-B\& SM-O) have denser and homogeneous structure, their large pores decreased and micro pores increased. The vacuums of specimens containing these admixtures and after these cycles of durability test were filled with prismatic new formations and showed a very small shrinkage cracks between cement paste and filling materials (Fig.11 de). The suggested admixture (SM-O) had a better effect on decreasing shrinkage cracks of tested specimens compared to the other admixtures (as shown in Fig. 11f).

The positive influence of the suggested organic admixtures on improvement properties of the microstructure formation of the hardened concrete may be explained by their positive influence on regulating the micro structure formation of cement paste and produce denser, homogeneous and impermeable concrete. Consequently, the bond forces between cement paste and filling materials increased while the internal large pores and cracks decreased, the micro pores increased and the properties of the microstructure were improved.

\section{CONCLUSIONS}

Based on the results of the experiments carried out on the concrete mixes and specimens containing in their compositions alkali wastes of oil and cellulose paper industries and hardened in different concentrations of sodium and magnesium sulfate solutions for a period of 7 months and exposed to different cycles of durability tests, the following conclusions can be drawn out:

1- Chemical analysis of alkali wastes, optimum composition of all components of the suggested admixtures (SM-S, CM-B \& SM-O) containing alkali wastes from oil and cellulose paper industries and production of them in a liquidity solution were successfully and experimentally achieved.

2- Water-cement ratio and sedimentation index of concrete mixes was clearly affected by the dose and type of the admixture. By increasing the dose of the suggested admixtures (DM2, SM-S, CM-B \& SM-O) from 0.0 to $0.75 \%$ by weight of cement, W/C decreased respectively by about $36,30,15 \& 7 \%$. Also, sedimentation index decreased respectively by about $32,39,40 \& 41 \%$ compared to the control mix without admixtures.

3- Optimum dose of each admixture, at which occurs maximum values of compressive strength and minimum values of water absorption was determined and equals $0.25 \%$ from weight of cement. At which, compressive strength of concrete specimens modified with the organic admixtures (SM-S, CM-B\&SM-O), at age of 7 months hardening in fresh water, increased respectively by about $23,20 \& 18 \%$. But, it increased by about $48 \%$ for concrete specimens modified with the control plasticizing admixture (DM2) compared to the control specimens without admixtures. 
4- The suggested admixtures (type SM-S, CM-B, \& SM-O) increased cubic compressive strength of concrete specimens hardened in aggressive sulfate solutions $\left(6 \% \mathrm{Na}_{2} \mathrm{SO}_{4}+3 \% \quad \mathrm{MgSO}_{4}\right)$ after 7 months by about 46, 37, \& $38 \%$ respectively compared to the control specimens hardened in the same conditions. Also, these admixtures have a good effect than the control plasticizing admixture (type DM2).

5- The increase of the concentration of the surrounded sodium and magnesium sulfate solutions from $3 \%$ to $9 \%$ had a neglected influence on reducing compressive strength of organic concrete specimens, after 7 months hardening in these conditions, modified with the suggested organic admixtures. But, it increased the reduction of compressive strength of control specimens without admixtures and with the control plasticizing admixtures (DM2) by about $11 \% \& 21 \%$ respectively compared with those hardened in fresh water.

6- After 50-cycles of durability tests, control specimens without admixtures and with the control plasticizing admixture (DM2) showed a large decrease of their compressive strength by about $36 \%$ \& $51 \%$ respectively. But, specimens modified with the suggested admixture (SM-S, CM-B \&SM-O) showed respectively a very small decrease of their compressive strength by about 3, $2 \& 4 \%$ only compared with the same specimens before these cycles of durability test.

7- The suggested admixtures (DM2, SM-S, CM-B \&SM-O) increased compressive strength and durability index of concrete specimens after 50 cycles of durability test by about $19,86,84 \& 76 \%$ respectively compared to the control specimens without admixtures. The suggested admixtures showed a better influence compared to the control plasticizing admixtureDM2.

8- The suggested admixtures (DM2, SM-S, CM-B \&SM-O) decreased water absorption and increased durability index of concrete specimens after 50 cycles of durability test by about $6,61,62 \& 66 \%$ respectively. Also, they decreased moisture adsorption of concrete specimens by about $9,61,65 \& 66 \%$ respectively after this type of durability compared to the control specimen without admixtures.

9- Electronic and microscopic analysis on concrete specimens exposed to 50 cycles of durability tests at age 228 days showed that:

- Control specimen without admixtures showed appearance of extended wide and large open cracks between cement paste and filling materials in the addition of different small shrinkage cracks in the cement paste and its structure became non homogeneous.

- Specimens with the control admixture (DM2) showed also appearance of different large and small cracks between cement paste and filling materials accompanied by small shrinkage cracks in the cement paste and its structure was homogeneous than the control ones.

- Specimens modified with the suggested admixtures (SM-S, CM-B\& SM-O) have denser and homogeneous structure, their large pores decreased and micro pores increased. The vacuums of specimens containing these admixtures and after these cycles of durability test were filled with prismatic new formations and showed very small shrinkage cracks between cement paste and filling materials. The suggested economic admixture (SM-O) had a better effect on decreasing shrinkage cracks compared to the other admixtures. 


\section{REFERENCES}

[1] M.D. Cohen, " Theories of expansion in sulfoaluminate - type expansive cements", Cement and Concrete Research 13, 1983, pp. 809-818.

[2] D. Bonen and M.D. Cohen, "Magnesium sulfate attack on Portland cement paste: I. Micro structural analysis ", Cement and Concrete Research 22, 1992, pp. 169180.

[3] M. Santhanam, M.D. Cohen and J. Olek, " Mechanism of sulfate attack: A fresh look", Part 1: Summary of experimental results, Cement and Concrete Research 32, 2002, pp. 915.

[4] Powers, T.C., Copeland, L.E., Hayes, J.C., and Mann, H.H., "Permeability of Portland Cement Pastes", ACI Journal proceedings, Vol.51, 1975.

[5] M.D. Cohen, A. Bentur, "Durability of Portland Cement, silica fume pastes in magnesium sulfate and sodium sulfate solutions", ACI Material Journal, Vol. 85, 1988, pp. 148-157.

[6] R.S. Gollop, H.F.W. Taylor, "Micro structural and micro analytical studies of sulfate attack: I. Ordinary Portland cement paste", Cement and Concrete Research 22, 1992, pp. 1027.

[7] J. W. Wang, "Sulfate attack on hardened cement paste", Cement and Concrete Research 24, 1994, pp. 735.

[8] P.K. Mehta, "Magnesium sulfate attack on Portland cement concrete another look", Cement and Concrete Research 13, 1983, pp. 401.

[9] P.J. Tikalsky, R.L. Carrasquillo, " Influence of fly ash on the sulfate resistance of concrete", ACI Structural Journal, Vol. 89, 1992, pp.69.

[10] K. Torii, M. Kawamura, "Effects of fly ash and silica fume on the resistance of mortar to sulfuric acid and sulfate attack", Cement and Concrete Research 25, 1995, pp. 759-768.

[11] N. Smaouia, M. A. Bérubé, B. Fournierc, B. Bissonnetted and B. Durand, Effects of alkali addition on the mechanical properties and durability of concrete", Cement

and Concrete Research, vol. 35, ISSUE 2, February 2005, pp. 203-212.

[12] Saeed Ahmad, Attaullah Shah and Karamet Ali, " Effect of water reducing concrete admixtures on the properties of concrete ", 29th Conference on our world in concrete and structures, Singapore, 25-26 August 2004.

[13] Hegerovitsh, M.E., soloviev, V.E., and Tomashpolske, A.D., "Complex admixture for concrete mixes", A.C. No. 769212, USSR, Pub in B.E., No. 2, 1981.

[14] Batrakov V.G., Falekman V.R., and Venogradof U.M., "Perspective of producing and using admixtures for concrete and reinforced concrete", Journal of concrete and Reinforced concrete, No., 4, Moscow, 1989.

[15] Rashwan, M.M., "Improvement of the properties of concrete with hydrophopizing admixtures in hot and dry weathering conditions", Ph.D. thesis Eng - Akad. Alma-Ata, 1995.

[16] 16.Rashwan, M.M., "Study of the possibility of producing new complex hydrophobizing admixtures for improvement of the cement materials properties ", Bulletin of the faculty of Engineering, Assiut University Vol .24, No.2, July 1996. 
[17] Mahmoud, H.A., Rashwan, M.M., Aly, G.A., and Abu El-fadel, M.M., "Effect of using complex non-traditional admixtures on the mechanical properties of cement mortar" 8th International Exhibition \& Conference for Building \& Constructions, Cairo, Egypt, June 2001.

[18] Mahmoud, H.A., Rashwan, M.M., Aly, G.A., and Abu El-fadel, M.M.," Durability of cement mortar affected by complex non-traditional admixtures", Journal of Engineering Sciences, Assiut University, Vol. 30, No. 3, pp. 631-645, July 2002.

\section{مقاومة الضغط وقوة التحمل مع الزمن للخرسانة المحتوية علي مخلفات قلوية من

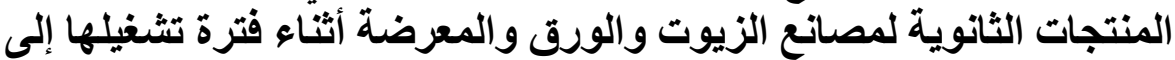 ظروف بيئية قاسية}



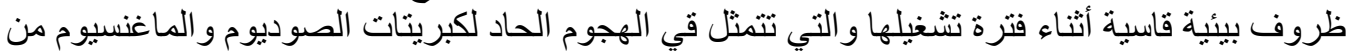

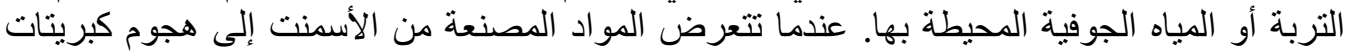

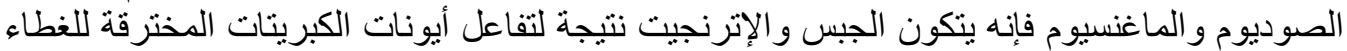

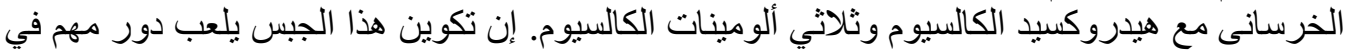

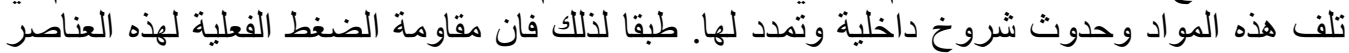

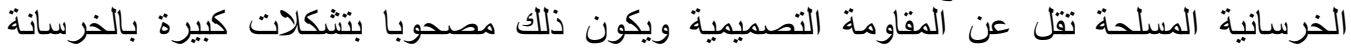
وبالتالي يحدث نقص كبير في قوة تحمل هذه العناصر مع الزمن مما يقلل من العمر الافتراضي لهي لها. لللك أصبحت الحاجة ماسة وضرورية إلى استخدام إضافات فعالة و اقتصادية لحماية العادية العناصر

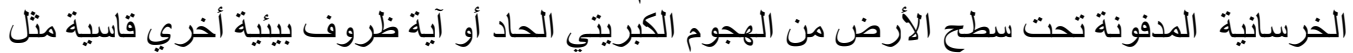

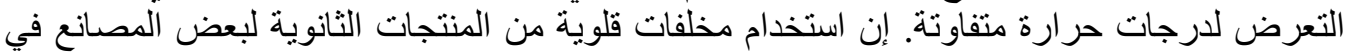

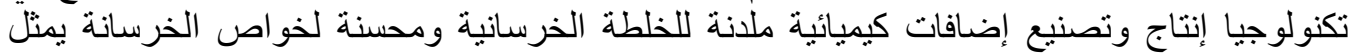
در اسة علمية وعملية شيقة خاصة من الناحية الاقتصادية والبيئية.

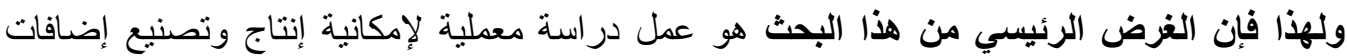

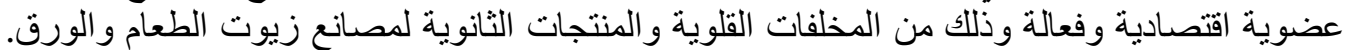

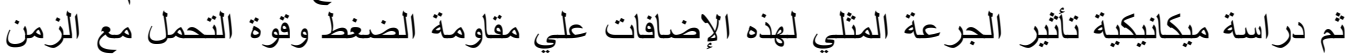



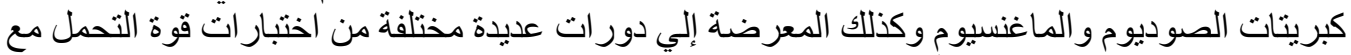
الزمن ـ إن المتغيرات الرئيسية التي تمت دراستها في هذا البحث علي عدد 384 عينة من المكعبات التئ

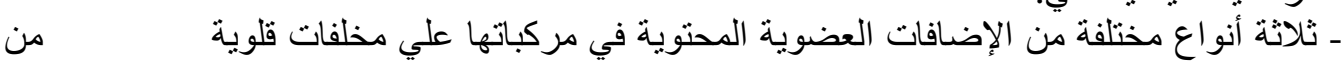

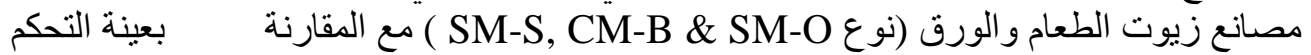
) بدون إضافات وكذلك بعينة تحكم مع إضافة ملدنة معروفة بالسوق المعام المصري


ـ ثلاثة تركيز ات مختلفة من محاليل كبريتات الصوديوم و والماغنسيو م المحيطة بالعينات: مجمو عة (أ) من

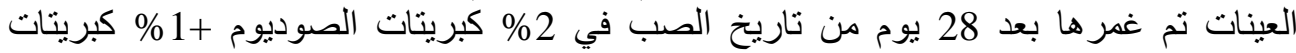

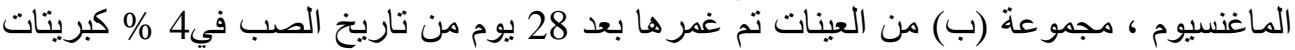


الصوديوم +2\% كبريتات الماغنسيوم ، مجمو عة (ج) من العينات تم غمر ها بعد 28 يوم من تاريخ

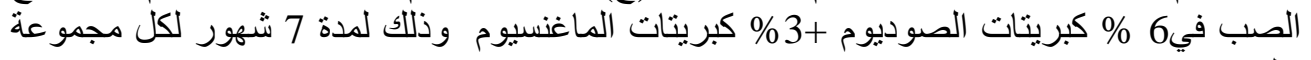

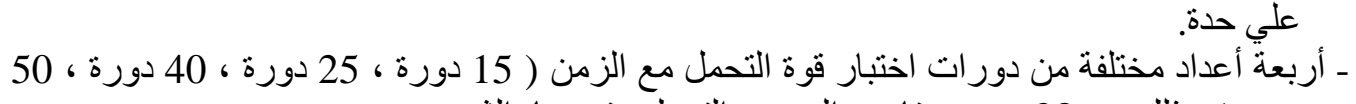

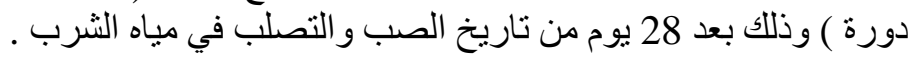

لقد أوضحت نتائج الفحوص المعملية أنه قد تم بنجاح تحضير إضافات عضوية جديدة من مخلفات

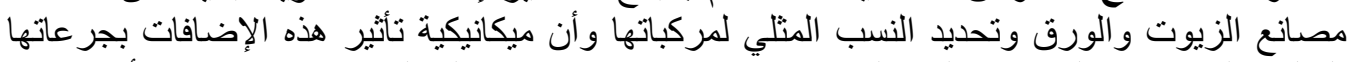

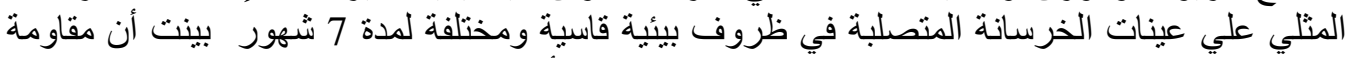

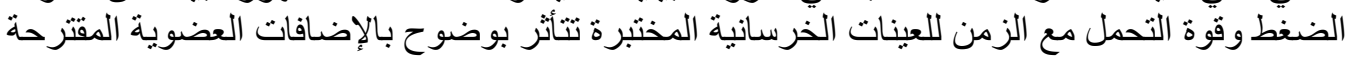


الزمن كما يلي : الزيل

عينات الخرسانة المحتوية على هذه الإضافات(SM-S, CM-B \&SM-O) و والمتصلبة في



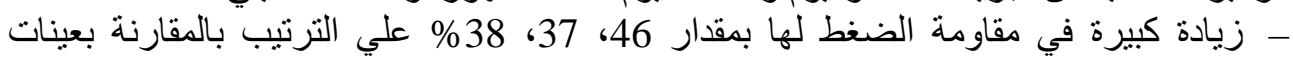

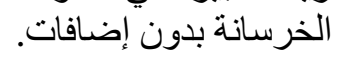

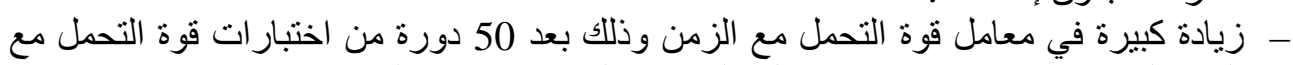

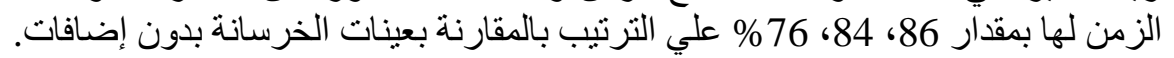

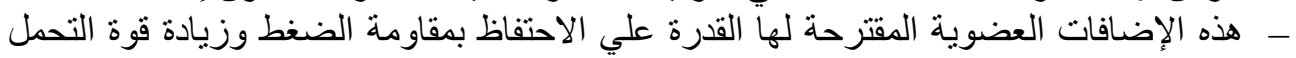

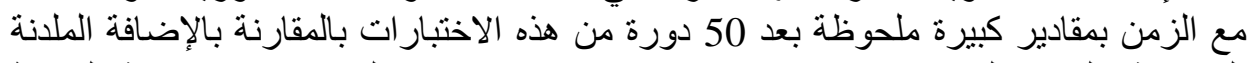

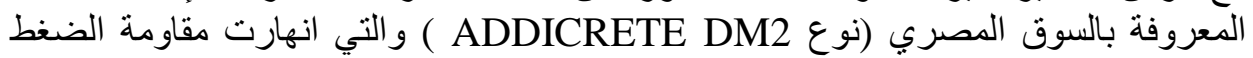

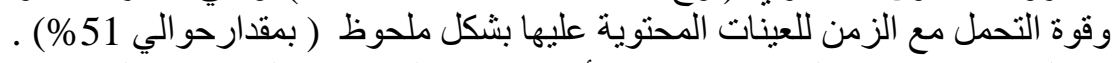



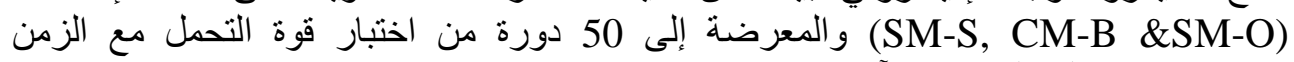
(عمر 228يوم) لها الخو اص الآتية:

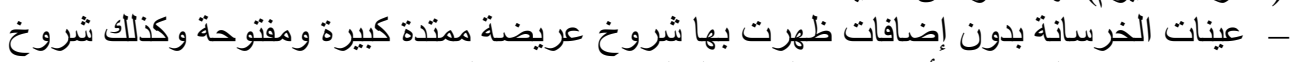

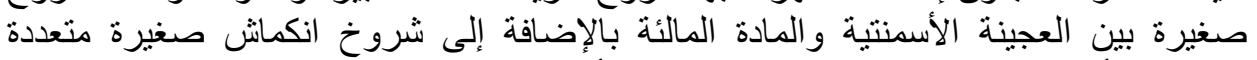

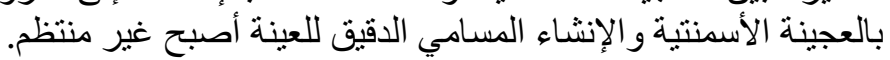

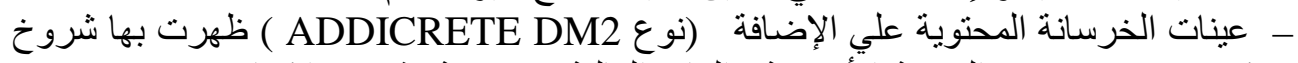

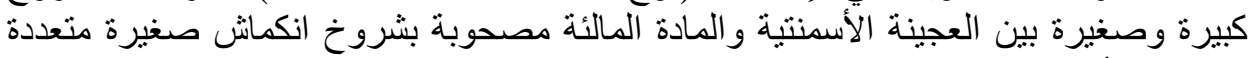



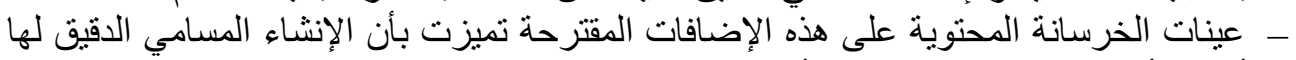

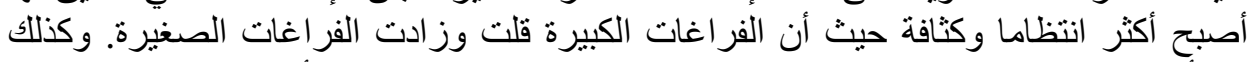

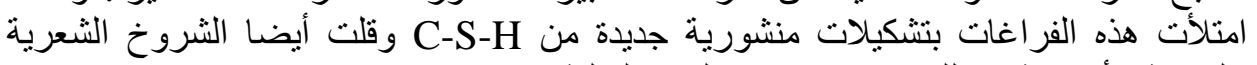
بالعجينة الأسمنتية وكذلك فيما بينها وبين المادة المالئة . 